FIU Law Review

Volume 13

Number 2 Decanal Issue

Article 8

Fall 2018

\title{
Florida's Certificate of Need: A Prescription for Government- Private Collusion and Antitrust Violation
}

Dane Stuhlsatz

J.D., 2018, Florida International University College of Law

Follow this and additional works at: https://ecollections.law.fiu.edu/lawreview

Part of the Law and Economics Commons

Online ISSN: 2643-7759

\section{Recommended Citation}

Dane Stuhlsatz, Florida's Certificate of Need: A Prescription for Government-Private Collusion and Antitrust Violation, 13 FIU L. Rev. 241 (2018).

DOI: https://dx.doi.org/10.25148/lawrev.13.2.8

This Comment is brought to you for free and open access by eCollections. It has been accepted for inclusion in FIU Law Review by an authorized editor of eCollections. For more information, please contact lisdavis@fiu.edu. 


\section{FLORIDA's CERTIFICATE OF NeED: A PRESCRIPTION FOR GOVERNMENT-Private COLLUSION AND ANTITRUST VIOLATION}

Dane Stuhlsatz*

But competition does not mean that anybody can prosper by simply imitating what other people do. It means the opportunity to serve the consumers in a better or cheaper way without being restrained by privileges granted to those whose vested interests the innovation hurts.

-Ludwig von Mises

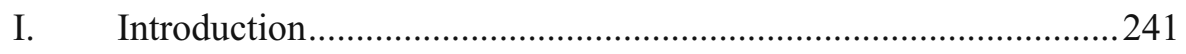

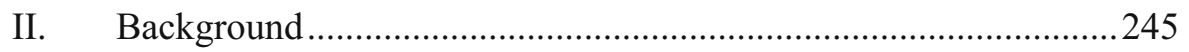

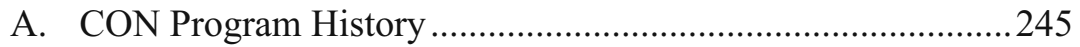

B. Federal Antitrust Laws .........................................................247

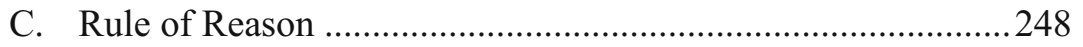

D. State-Action Antitrust Immunity Doctrine ............................252

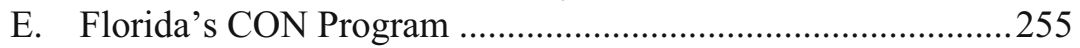

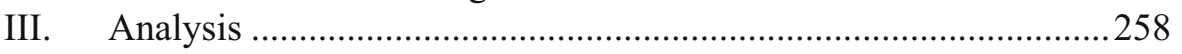

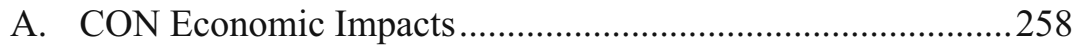

B. Perverse Incentives Create Perverse Results ............................264

C. Florida's CON Program Violates the Rule of Reason and

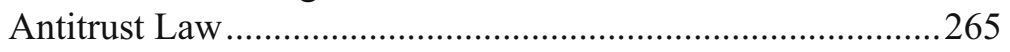

D. Parker Immunity Should Not Be Applied to Florida's CON

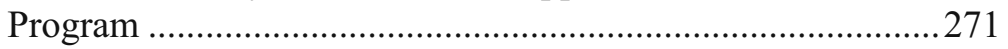

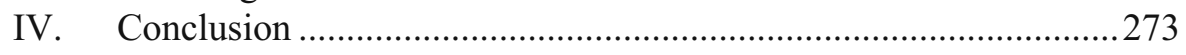

\section{INTRODUCTION}

Florida is one of thirty-five states, and the District of Columbia, that still currently has "certificate-of-need" $(\mathrm{CON})$ programs. ${ }^{1} \mathrm{CON}$ programs operate

\footnotetext{
* J.D., 2018, Florida International University College of Law; B.S., Friends University. A special thank you to my family and friends for their constant love and support, and to Professor Elizabeth Price Foley, without whose guidance this article would not have been possible.

1 Matthew D. Mitchell \& Christopher Koopman, 40 Years of Certificate-of-Need Laws Across America, George Mason Univ. Mercatus Ctr. (Sept. 27, 2016), https://www.mercatus.org/publication/40-years-certificate-need-laws-across-america.
} 
as government permission slips, without which, health care providers are prohibited from entering into or expanding within a health care market. ${ }^{2}$ Believing health care markets posed special problems, which free-markets were incapable of coping with, governments began to institute CON programs over fifty years ago. ${ }^{3}$ In particular, when CON programs began to be enacted, legislators were most concerned with the market reimbursement incentives of health care. ${ }^{4}$

In order to recoup capital expenditures, health care providers operated on what was known as a "cost plus" basis. ${ }^{5}$ Under a "cost plus" reimbursement structure, providers, in an effort to compete with each other, would invest in newer and better health care technology and capacity and recover the costs by charging a premium on the newly provided service to pay for the expenditure. ${ }^{6} \mathrm{CON}$ program proponents saw this as a perverse incentive for "unnecessary spending.," Viewing this reimbursement structure as a "market failure," proponents considered state intervention into the health care sector as a necessity to protect consumers. ${ }^{8}$ However, fifty years of data on the effects of CON programs has demonstrated that CON programs do not protect consumers.

In seeking to remedy this alleged "market failure," CON programs are aimed at assuring a stable market in several health care goods and services, including but not limited to: (1) maintaining an adequate supply of health care resources; (2) increasing care quality; (3) suppressing care costs; and (4) ensuring rural and underserved community access to care. ${ }^{9}$ However, the Mercatus Center at George Mason University has conducted research which identifies several areas that have fallen well short of CON program intended effects. ${ }^{10}$ Researchers have found a more limited supply of hospital beds, advanced imaging equipment, and fewer rural hospitals. ${ }^{11}$ However, these policy failures alone are not the problem with CON programs. The real problem with $\mathrm{CON}$ programs is the rationale that $\mathrm{CON}$ programs are targeted at consumer benefit and protection because, in continuing to support CON programs, proponents appeal to good intentions to support bad and failing

2 Id.

3 Maureen K. Ohlhausen, Certificate of Need Laws: A Prescription for Higher Costs, 30 ANTITRUST 50, 51 (2015).

4 Id.

5 Id.

6 See id.

7 Id.

8 Id.

9 Mitchell \& Koopman, supra note 1.

10 Id.

11 Id. 
policies. ${ }^{12}$ In this way, CON programs continue to persist long past their usefulness and in spite of their empirical failures.

Operating behind all of these policy failures is a consumer protection double-standard. Antitrust law, in general, is aimed at protecting consumers from collusion and cheating in the free-market. ${ }^{13}$ Government steps in to assure consumers that there will be a level playing field when it comes to access to important resources and services, such as health care. ${ }^{14}$ Government asserts its authority to prevent private actors from colluding, or otherwise gaming the market system, to take advantage of consumers with inflated prices or artificially limited supplies. ${ }^{15}$ Putting the arguments for or against that framework in terms of protecting consumers aside, if the principles that undergird that framework are sound, they should be applied equally to all, regardless of whether the actors are both private companies or a private company and the state. Through CON programs, state and local governments engage in the very types of collusive activities that harm consumers, which antitrust laws are aimed at preventing among private actors alone. ${ }^{16}$

In determining whether private actors have violated antitrust laws, courts apply a test known as the "rule of reason." ${ }^{.17}$ Because not all collusive behavior is necessarily harmful to markets or consumers, the "rule of reason" weighs the benefits to markets and consumers of certain private actions against the harms that are caused by those actions. ${ }^{18}$ The test consists of three prongs:

(1) What harm to competition results or may result from the collaborators' activities? (2) What is the object they are trying to achieve and is it a legitimate and significant one? That is, what are the nature and magnitude of the "redeeming virtues" of the challenged collaboration? (3) Are there other and better ways by which the collaborators can achieve their legitimate objectives with fewer harms to competition? That

12 Peter Doherty, Certificates of Need: A Bad Idea Whose Time Has Passed, J. JAMES MADISON INST., Winter 2001, at 1, 10, 12.

13 The Antitrust Laws, FED. TRADE COMM'N, https://www.ftc.gov/tips-advice/competitionguidance/guide-antitrust-laws/antitrust-laws (last visited Dec. 23, 2016).

14 See Dealings in the Supply Chain, FED. TRADE COMM'N, https://www.ftc.gov/tipsadvice/competition-guidance/guide-antitrust-laws/dealings-supply-chain (last visited Dec. 23, 2016).

15 See generally The Enforcers, FED. TRADE COMM'N, https://www.ftc.gov/tipsadvice/competition-guidance/guide-antitrust-laws/enforcers (last visited Dec. 23, 2016).

16 Ohlhausen, supra note 3, at 52.

17 Phillip AREEDA, Fed. Judicial CTR., FJC-ETS-81-1, THE “RulE OF REASON” IN ANTITRUST ANALYSIS: GENERAL ISSUES 2 (1981).

18 Id. 
is, are there "less restrictive alternatives" to the challenged restraint? ${ }^{19}$

If the harms outweigh the benefits, then the "rule of reason" test is failed, and the actors who engaged in the activity are deemed to have violated the antitrust laws. ${ }^{20}$ In contrast, if the benefits outweigh the harms, then the action is deemed not to have violated antitrust laws, even if on the surface the actions appear to be violative of antitrust laws. ${ }^{21}$

The "rule of reason" test should be applied to CON programs to determine whether the harms outweigh the benefits. If consumer protection is the goal of antitrust law (and governments are logically and ethically consistent when applying antitrust law principles to their own action as vigorously as they do to private action) then $\mathrm{CON}$ programs which violate the "rule of reason" should be abandoned. Simply because governments can exempt themselves from their own rules does not mean that they should.

Part II of this note will address the various histories at play in the following legal analysis. First, the history of CON programs dating from the first CON program in the country, the Metcalf-McCloskey Act in 1964, up to today, will be addressed, focusing on the rationales behind various CON programs. Next, the history of antitrust law, from the Sherman Antitrust Act up to today, will be explored, paying special attention to the principles and rationales that undergird antitrust law. The "rule of reason" will be addressed and identify why and what actions have been deemed violative of the "rule of reason" test, and therefore, violative of antitrust law. A few recent cases will be discussed where antitrust law has been applied to anticompetitive state behavior. The Parker immunity doctrine will be addressed as a possible defense to CON programs from antitrust enforcement. Finally, the economic impacts of Florida's CON program on the Florida health care market will be identified.

Part III will apply the "rule of reason" to the effects of Florida's CON program. Whether there is more of a burden to Florida health care consumers than benefit will be assessed to determine if Florida's CON program is violating the consumer protection principles underlying antitrust law. Parker immunity will be applied to Florida's CON program to determine whether it deserves the state exception from antitrust law.

Ultimately, this note will focus less on whether government action can harm consumers and more on whether it should. CON programs that harm consumers more than they benefit them should be subjected to the same rigors of the "rule of reason" as private action. CON programs, such as 
Florida's, should be abandoned when the data shows that they are all buck and no bang.

\section{BACKGROUND}

\section{A. CON Program History}

The first CON program in the country was the Metcalf-McCloskey Act, which was passed in New York in 1964. ${ }^{22}$ The Metcalf-McCloskey Act arose out of a study conducted by a community health planning council, which looked into the community need for more hospital beds. ${ }^{23}$ The community health planning council, comprised of health care consumers, insurers, and providers, was concerned that, if left to market incentives, the New York market would become over-saturated with a supply of hospital beds. ${ }^{24}$ From the time of the passage of the Metcalf-McCloskey Act until the passage of Section 1122 of the Social Security Act, eighteen additional states passed their own CON programs. ${ }^{25}$

Section 1122 of the Social Security Act was passed with the belief in the alleged virtues of CON programs to keep costs down while providing ubiquitous access to health care. The goal of CON programs was to maintain and enhance the quality of care and to control health care costs in local communities by "promoting a governmentally defined and overseen 'rational distribution' of certain health care services." ${ }^{26}$ The practical effect of this "rational distribution" limited the number of health care providers who offered the same services within a given market. ${ }^{27}$ "Generally speaking, approval was required before a facility or provider could initiate projects requiring capital expenditures above a certain dollar amount, and before they could introduce new services, expand existing services, or increase the number of beds." 28

However, because several states apparently were not "drinking the CON program kool-aid," the federal government passed Section 1122 to incentivize the reluctant states to adopt their own CON programs. ${ }^{29}$ Section

\footnotetext{
22 Herbert Harvey Hyman, Health Planning: A Systematic Approach 253 (2d ed. 1982).

23 Marshall B. Kapp \& Leslie M. Beitsch, Health Found. of S. Fla., Florida's HeAlthCARE CERTIFICATE OF NEED 1 (2014), http://www.hfsf.org/wpcontent/uploads/2016/12/certificate_of_need.pdf.

24 See id.

25 HYMAN, supra note 22.

26 Doherty, supra note 12, at 12.

27 Id.

$28 \quad I d$.

29 HYMAN, supra note 22.
} 
1122 operated as a "stick" disguised as a "carrot" to achieve wider CON program acceptance among the states. "While Section 1122 involved a voluntary agreement between the state and the federal government, it was passed with an implied threat of mandatory federal regulation if the states did not follow up with some form of health facilities regulation." ${ }^{30}$

As a result of the problems caused within the health care system arising from the massive influx of federal funds, Congress passed the National Health Planning and Resources Development Act (NHPRDA) in 1974. ${ }^{31}$ Among other problems caused by federal intervention into health care markets, Congress found, "[t]he massive infusion of Federal funds into the existing health care system has contributed to inflationary increases in the cost of health care and failed to produce adequate supply or distribution of health resources, and consequently has not made possible equal access to everyone for such resources." 32 Before passage of the NHPRDA, one would think the federal government would have learned its lesson; they obviously identified part of the problem (the influx of federal funds). But, not to be outdone by itself, Congress passed the NHPRDA anyway, which required states to implement CON programs in order to receive funding through certain federal programs. ${ }^{33}$

By 1908, In response to the NHPRDA, every state except Louisiana had adopted their own CON program in order to continue receiving federal funding for their various health care programs. ${ }^{34}$ However, after failing to achieve its goals, the NHPRDA was repealed in $1986 .{ }^{35}$ When the NHPRDA was repealed, several states began to repeal their own CON programs. ${ }^{36}$ "By 1990, California, Colorado, Idaho, Kansas, Minnesota, New Mexico, South Dakota, Texas, Utah, Wisconsin, and Wyoming had repealed their CON programs." ${ }^{37}$ Today, thirty-five states and the District of Columbia, including Florida, retain their CON programs. ${ }^{38}$

$30 \quad I d$.

31 National Health Planning and Resources Development Act of 1974, Pub. L. No. 93-641, § 2(a)(2), 88 Stat. 2225 (1975).

32 Id.

33 Id. at $\S 1516(\mathrm{a})-(\mathrm{b})$.

34 Ohlhausen, supra note 3.

35 Melissa D. Cupp \& Brian Kaser, State Bar of Mich. Health Care Law Section, CON BASICS IN MICHIGAN 3 (2014), https://higherlogicdownload.s3.amazonaws.com/MICHBAR/f8a8a213d7d6-49c4-bdff-e6c7a728e471/UploadedImages/pdfs/CONbasics.pdf.

36 Mitchell \& Koopman, supra note 1.

37 Id.

38 Id. 


\section{B. Federal Antitrust Laws}

Three federal laws - the Sherman Act, the Clayton Act, and the Federal Trade Commission Act-comprise the core of antitrust law today. ${ }^{39}$ In particular, the Sherman Antitrust Act was passed as a "comprehensive charter of economic liberty aimed at preserving free and unfettered competition as the rule of trade." 40 The Sherman Antitrust Act has been narrowed to prohibit only restraint of trade which is unreasonable. ${ }^{41}$ Under the Sherman Antitrust Act, competitors cannot restrain trade by agreeing to a fixed price for a good or service. ${ }^{42}$ Additionally, monopolies are prohibited by the Act if they are cheating or not competing fairly for the benefit of consumers. ${ }^{43}$

The Clayton Act forbids mergers and acquisitions that "may be substantially to lessen competition, or to tend to create a monopoly," as well as discriminatory prices, services, and allowances when merchants deal with each other. ${ }^{44}$ In response to the use of the Sherman Antitrust Act to break up trusts, businesses began to look to merging with and acquiring one another to control pricing and production. ${ }^{45}$ In 1914, the Clayton Act was passed to give the government the power to stop mergers or acquisitions that stifled competition to the detriment of consumers. ${ }^{46}$

The Federal Trade Commission Act, which created the Federal Trade Commission (F.T.C.), prohibits "unfair methods of competition" and "unfair or deceptive acts or practices." ${ }^{47}$ Under the Act, the F.T.C. has the authority to investigate and stop methods of competition or deceptive practices which it finds to be in violation of antitrust laws. ${ }^{48}$ Over the years, the federal antitrust laws have had one primary goal: "to protect the process of competition for the benefit of consumers, making sure there are strong incentives for businesses to operate efficiently, keep prices down, and keep quality up." 49

\footnotetext{
39 The Antitrust Laws, supra note 13.

40 Id.

$41 \mathrm{Id}$.

42 Fed. Trade Comm'N, F.T.C. FACt SheEt: Antitrust Laws: A Brief History, [hereinafter F.T.C. FACT SHEET], https://www.consumer.ftc.gov/sites/default/files/games/offsite/youarehere/pages/pdf/FTC-Competition_Antitrust-Laws.pdf.
43 Id.
44 The Antitrust Laws, supra note 13.
45 F.T.C. FACT SHEET, supra note 42.
46 Id.
47 The Antitrust Laws, supra note 13.
48 F.T.C. FACT SHEET, supra note 42.
49 The Antitrust Laws, supra note 13. 


\section{Rule of Reason}

Section 1 of the Sherman Antitrust Act states, "[e]very contract, combination in the form of trust or otherwise, or conspiracy, in restraint of trade or commerce among the several States, or with foreign nations, is hereby declared to be illegal." ${ }^{\circ 0}$ The early concern over enforcement of the statute was driven by the word "every." 51 Early courts struggled over how to enforce the Sherman Antitrust Act because the very point of privately contracting at all is to restrain trade to at least some degree; therefore, how could it be possible that "every" contract in restraint of trade could be prohibited by the Act? ${ }^{52}$ Standard Oil Co. v. United States, 221 U.S. 1 (1911), settled this problem by stating:

That to protect the freedom of contract of the individual not only in his own interest, but principally in the interest of the common weal* [sic], a contract of an individual by which he put an unreasonable restraint upon himself as to carrying on his trade or business was void. And that at common law the evils consequent upon engrossing, etc., caused those things to be treated as coming within monopoly and sometimes to be called monopoly and the same considerations caused monopoly because of its operation and effect, to be brought within and spoken of generally as impeding the due course of or being in restraint of trade. ${ }^{53}$

To determine which contracts went too far in restraint of trade to fall within the proscribed activities of the Act, Standard Oil stated, "[i]f the criterion by which it is to be determined in all cases whether every contract, combination, etc., is a restraint of trade within the intendment of the law, is the direct or indirect effect of the acts involved, then of course the rule of reason becomes the guide. ..."54

In Chicago Board of Trade v. United States, 246 U.S. 231 (1918), Justice Brandeis identified the factors which differentiate the practices that

$50 \quad 15$ U.S.C.A $\S 1$ (West 2004).

51 AREEDA, supra note 17, at 1 .

52 See United States v. Trans-Missouri Freight Ass'n, 166 U.S. 290, 340 (1897) (stating “[u]nder these circumstances we are, therefore, asked to hold that the act of Congress excepts contracts which are not in unreasonable restraint of trade, and which only keep rates up to a reasonable price, notwithstanding the language of the act makes no such exception. In other words, we are asked to read into the act by way of judicial legislation an exception that is not placed there by the lawmaking branch of the Government, and this is to be done upon the theory that the impolicy of such legislation is so clear that it cannot be supposed Congress intended the natural import of the language it used. This we cannot and ought not to do.").

53 Standard Oil Co. v. United States, 221 U.S. 1, $54-55$ (1911).

$54 \quad I d$. at 66. 
may suppress or destroy competition from those that promote it. ${ }^{55}$ Justice Brandeis stated:

To determine that question the court must ordinarily consider the facts peculiar to the business to which the restraint is applied; its condition before and after the restraint was imposed; the nature of the restraint and its effect, actual or probable. The history of the restraint, the evil believed to exist, the reason for adopting the particular remedy, the purpose or end sought to be attained, are all relevant facts. ${ }^{56}$

As a result of this early interpretation of the creation and implementation of the "rule of reason," three prongs were identified. ${ }^{57}$ First, "[w] hat harm to competition results or may result from the collaborators" activities?" 58 Second, "[w]hat is the object they are trying to achieve and is it a legitimate and significant one? That is, what are the nature and magnitude of the 'redeeming virtues' of the challenged collaboration?" 59 Finally, "[a]re there other and better ways by which the collaborators can achieve their legitimate objectives with fewer harms to competition? That is, are there 'less restrictive alternatives' to the challenged restraint?"60

Accordingly, the "rule of reason" establishes that not "every" contract that restrains trade is prohibited by the Act, but those contracts which unreasonably do so are ${ }^{61}$ Such a situation is present where efforts are made purely for the benefit of the offending party to the detriment of competitors, trade, and consumers. ${ }^{62}$ In United States v. American Tobacco Co., 221 U.S. 106 (1911), decided the same year as Standard Oil, the Supreme Court again applied the "rule of reason" to find unreasonable restraint of trade. ${ }^{63}$ American Tobacco Co. acquired several competitors through a variety of direct buys and stock acquisitions. ${ }^{64}$ American Tobacco proceeded to sell many of the acquired concerns within months, and ended up with a substantial share of the tobacco market in the country, as well as several areas of tobacco production throughout the country. ${ }^{65}$ The Court found both

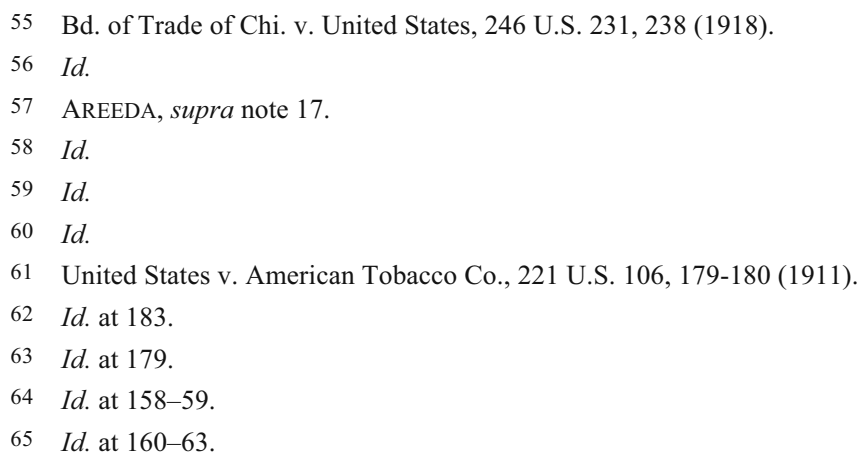


restraint of trade and monopolization because American Tobacco Co.'s practices created more burdens than benefits on markets and consumers. ${ }^{66}$

"Naked" restraint of trade, as opposed to restraint which has a socially beneficial "redeeming virtue," is easily condemnable under this three prong analysis. ${ }^{67}$ Where "naked" restraint is occurring, even the most tolerable of competition impairment between competitors would fail "rule of reason" analysis. ${ }^{68}$ However, restraint that has beneficial outcomes to consumers (i.e. a "redeeming virtue"), which the majority of cases that are subjected to "rule of reason" analysis are, is less certain to fail.$^{69}$ Of that type, the question must be asked: Does this particular restraint have a legitimate purpose? ${ }^{70}$ Only legitimacy can save a practice which restrains trade under the "rule of reason." "71 This legitimacy "lies in consistency with the law generally and consistency with the premises of the antitrust laws in particular."72

A group of engineers sought to restrain trade in National Soc. of Professional Eng'rs v. United States, 435 U.S. 679 (1978). ${ }^{73}$ The Supreme Court addressed the legitimacy of their objective to not compete with each other in price bidding for customers. ${ }^{74}$ The engineers would not bid with each other to win a contract for a customer, but instead, would only negotiate the

66 Id. at 183-84; see also Wilk v. Am. Med. Ass'n, 895 F.2d 352 (7th Cir. 1990) (The American Medical Association boycotted chiropractors as "unscientific." However, because the American Medical Association did not provide sufficient evidence to show that the chiropractic methods were in fact "unscientific," it was unable to show that their anti-competitive boycotts were not supported by a valid reason. Therefore, the Sherman Antitrust Act was violated.); Nat'1 Soc'y of Prof'1 Eng'rs v. United States, 435 U.S. 679 (1978) (Because the National Society of Professional Engineers required its members to not allow competitive bidding, pursuant to its code of ethics, the Court found this practice to be in violation of the Sherman Antitrust Act. Despite the National Society of Professional Engineers' claim that competition would be better fostered by the measure, the Court still found the measure to be restrictive of trade even though it [was not] necessarily price fixing, by definition, on its face. Because the Sherman Antitrust Act was violated, an injunction was an appropriate remedy to ensure that a recurrence of the violation and the consequences which stem from the measure would not be repeated). But see Bd. of Trade of Chi. v. United States, 246 U.S. 231 (1918) (The Chicago Board of Trade prohibited commodities traders from privately agreeing to sell or buy after the market closed for the day. The Board of Trade's stated reasons for the rule was to ensure that all traders had an equal chance to trade at a transparent market price. Although, it plainly restricted trading, the Court found that the rule was pro-competitive, and complied with the "rule of reason." Because this rule was a "good restraint of trade," it did not violate the Sherman Antitrust Act); Broad. Music v. Columbia Broad. Sys., 441 U.S. 1 (1979) (The "rule of reason" test is relaxed when blanket licenses are involved, which are required of all competitors in a market. Because they apply equally to all, blanket licenses are not necessarily considered price fixing.).

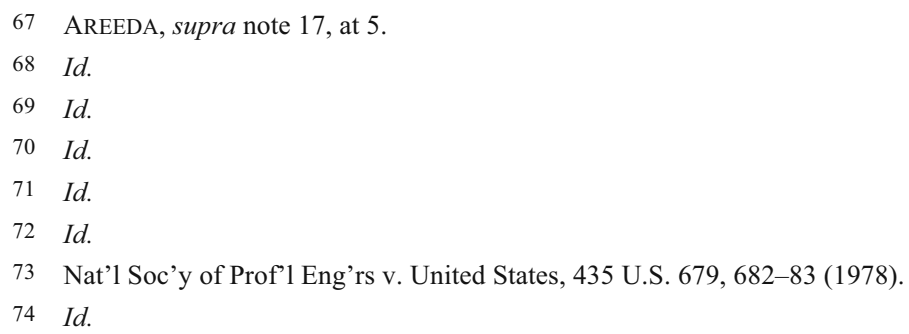


price with the customer after they were selected to complete a project. ${ }^{75}$ Although the scheme reduced price competition among the engineers, they defended the restraint on public safety grounds. ${ }^{76}$ The argument went that by restraining price competition, public safety would be enhanced because it would preclude inferior engineering work from competing with them. ${ }^{77}$ Lower courts refused to find that there was a relationship between the price competition, inferior engineering, and poor engineering that would lead to harms on public safety. ${ }^{78}$ In applying the "rule of reason," the Court upheld the lower courts' reasoning and rejected the engineers' claim without any findings of relationship between price bidding, inferior engineering, poor engineering quality, and diminished public safety. ${ }^{79}$ Because the limitation on competition via price bidding between engineers was inconsistent with the Sherman Antitrust Act's competition mandate, the action violated it in principle, and therefore, in practice. ${ }^{80}$

Once the dual hurdles of legitimate objective and restraint necessary to achieve that objective have been overcome, a restraint may still be struck down if the objective could be achieved through less-restrictive means ${ }^{81}$ This was dealt with in Cont'l T.V. v. GTE Sylvania, 433 U.S. 36 (1977). ${ }^{82}$ In Sylvania, the defendants employed a "location restriction" which forbade dealers of its products from selling the products from a location other than those Sylvania approved of. ${ }^{83}$ The dealers were not, however, restricted from selling to any customer that happened to be located outside of their prescribed location. ${ }^{84}$ Although the Court's analysis did not necessarily turn on Sylvania's choice of the less-restrictive limitation, the Court decided that a difference between a "location restriction" and customer or territorial restrictions was not sufficient to prohibit one restriction and not the other. ${ }^{85}$ The Court did not decide the reasonableness of the restraint before it, however, "[o]n remand the restraint was held reasonable, partly on the

75 Id.

76 Id. at 681.

77 Id.

$78 \quad$ Id. at 686.

79 Id.

80 Id. at 695-96 ("In our complex economy the number of items that may cause serious harm is almost endless - automobiles, drugs, foods, aircraft components, heavy equipment, and countless others, cause serious harm to individuals or to the public at large if defectively made. The judiciary cannot indirectly protect the public against this harm by conferring monopoly privileges on the manufacturers.").

81 AREEDA, supra note 17 , at 9.

82 Cont'1 T.V. v. GTE Sylvania, 433 U.S. 36, 37 (1977).

$83 I d$. at 38 .

84 Id.

85 Id. at 57. 
ground that the location restriction was one of the least restrictive forms of controlling intrabrand competition." $" 86$

\section{State-Action Antitrust Immunity Doctrine}

States, or regimes claiming to operate on the state's behalf, often appeal to what is known as the "Parker Immunity Doctrine" in defense of anticompetitive measures such as CON programs. ${ }^{87}$ The premise of the doctrine is that Congress, in enacting the Sherman Act, did not intend to restrain state behavior. ${ }^{88}$ In effect, the doctrine immunizes state action from antitrust scrutiny. ${ }^{89}$

In Parker v. Brown, 317 U.S. 341 (1943), the California Director of Agriculture instituted programs pursuant to the California Agricultural Prorate Act, which established programs for the marketing of agricultural commodities produced in the state. ${ }^{90}$ The intent of the programs was to "conserve the agricultural wealth" of the state by restricting competition among growers and maintaining prices in distribution to packers. ${ }^{91}$ Raisin producers challenged the Act as violative of the Sherman Antitrust Act. ${ }^{92}$ If the same scheme was undertaken by private actors, the Court said that it would violate the Sherman Antitrust Act. ${ }^{93}$ But, the Supreme Court held that the Sherman Antitrust Act did not apply to state actions, making the petitioner's actions immune. ${ }^{94}$

The Supreme Court further extended "Parker Immunity," in Cal. Retail Liquor Dealers Ass'n v. Midcal Aluminum, 445 U.S. 97 (1980), by including private action, so long as the private conduct was (1) "one clearly articulated

86 AREEDA, supra note 17, at 9.

87 In Cal. Retail Liquor Dealers Ass' $n$ v. Midcal Aluminum, 445 U.S. 97 (1980), a wine distributor sought an injunction against the state's wine pricing statute, which required them to file a fair trade contract or price schedule with the state. The fair trade contract or schedule set the terms for all wholesale transactions in that brand in a given area and fixed the price posted by a single wholesaler in a given area. Id. In F.T.C. v. Phoebe Putney Health Sys., 568 U.S. 216 (2013), the F.T.C. brought an action against a hospital authority in Georgia alleging that the purchase of another hospital violated antitrust laws. The hospital authority contended that its actions were contemplated by state legislation, and therefore, protect by the state-action antitrust immunity doctrine. Id. And, in N.C. State Bd. of Dental Exam 'rs v. F.T.C., 135 S. Ct. 1101 (2015), the North Carolina State Board of Dental Examiners invoked the state-action antitrust immunity doctrine to defend its licensing regime which consisted of a board of eight members, six of which had to be practicing dentists in the state.
88 Parker v. Brown, 317 U.S. 341, 350-51 (1943).
89 Id. at 351
90 Id. at 344.
91 Id. at 346.
92 Id. at 344.
93 Id. at 350.
94 Id. at $351-52$. 
and affirmatively expressed as state policy" and (2) that the policy was "actively supervised by the State itself." "In Midcal, the challenged California wine pricing statute was not granted immunity from the Sherman Antitrust Act because it did not meet the second prong of the Court's analysis. ${ }^{96}$ Under the statute, wine wholesalers were required to file a fair trade contract or price schedule with the state, which set the terms for transactions in that brand and bound all wholesalers in a given area. ${ }^{97}$ The Court found the California legislature to have clearly stated its policy purposes in permitting the price maintenance. ${ }^{98}$ However, California did not establish the appropriate prices or review the reasonableness of the price schedules. ${ }^{99}$

In reference to the "clearly articulated" prong from Midcal, the Supreme Court recently addressed an ambiguity in its application that arose from the "foreseeable result" standard of state legislation. ${ }^{100}$ The "foreseeable result" standard, first articulated in Hallie v. Eau Claire, 47 U.S. 34, 43 (1985), asserts that state policy is "clearly articulated" if the anticompetitive effect of the legislation was a "foreseeable result" of that legislation. ${ }^{101}$ In F.T.C. v. Phoebe Putney Health Sys., 133 S. Ct. 1003 (2013), the Supreme Court identified the contours of the "foreseeable result" standard because the Court stated that the Eleventh Circuit had applied the standard too loosely in finding "Parker Immunity" for a hospital merger in Georgia. ${ }^{102}$

95 Cal. Retail Liquor Dealers Ass'n v. Midcal Aluminum, 445 U.S. 97, 105 (1980) (quoting City of Lafayette v. La. Power \& Light Co., 435 U.S. 389, 410 (1978) (plurality opinion)); see also New Motor Vehicle Bd. of Cal. v. Orrin W. Fox Co., 439 U.S. 96 (1978) (applying antitrust immunity to a California program that required state approval for the placement of new car dealership locations which provided for a State hearing if a franchisee protested the establishment or relocation of a competing dealership); Bates v. State Bar of Ariz., 433 U.S. 350, 362 (1977) (finding immunity for Arizona's rules against lawyer advertising because of Arizona's "clear articulation of the State's policy with regard to professional behavior." Further, the rules were "subject to pointed re-examination by the policymaker - the Arizona Supreme Court-in enforcement proceedings"). But see Cantor v. Detroit Edison Co., 428 U.S. 579 (1976) (finding no antitrust immunity for the Michigan Public Service Commission, which regulated the distribution of electricity within the state as well as the distribution of lightbulbs, because the State merely passively accepted the public utility's tariff on competitors); Goldfarb v. Va. State Bar, 421 U.S. 773, 791 (1975) (in finding no antitrust immunity for fee schedules, enforced by a state bar association, because the schedules were not mandated by ethical standards by the State Supreme Court, the Court stated that, "[i]t is not enough that ... anticompetitive conduct is 'prompted' by state action; rather, anticompetitive activities must be compelled by direction of the State acting as a sovereign").

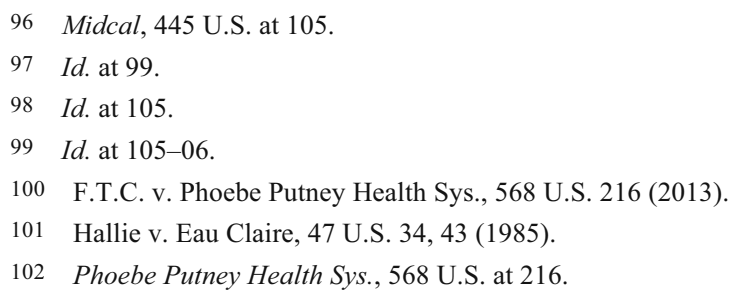


As a result of a merger between the Hospital Authority of AlbanyDougherty County and Palmyra Medical Center, the Albany-Dougherty Authority controlled eighty-six percent of the local market. ${ }^{103}$ The Eleventh Circuit found the power of authority to acquire other hospitals, granted by the State of Georgia to Hospital Authorities, made the potential anticompetitive effects of hospital acquisition a "foreseeable result" of the legislation. ${ }^{104}$ In disagreeing with the Eleventh Circuit, the Supreme Court stated that to be "clearly articulated," legislation authorizing anticompetitive actions must be the "inherent, logical, or ordinary result of the authority delegated by the state legislature." 105 Rather than clearly articulating such anticompetitive power on the Hospital Authorities, the Court likened the powers conveyed to the Hospital Authorities to the general powers bestowed on private corporations. ${ }^{106}$

N.C. State Bd. of Dental Exam'rs v. F.T.C., 135 S. Ct. 1101 (2015), recently decided by the United States Supreme Court, addressed the "active supervision" prong of Midcal. ${ }^{107}$ In N.C. State Bd. of Dental Exam'rs, a state dental board, staffed by licensed practicing dentists, sent cease-and-desist letters to non-dentists who offered teeth-whitening services at mall kiosks, beauty salons, and similar locations. ${ }^{108}$ Eight of the ten members of the Board were dentists, elected by other dentists, and had teeth-whitening services in their own practices which they earned "tens of thousands of dollars" from. ${ }^{109}$ These board members were determined by the Court to be active market participants in the occupation they were regulating. ${ }^{110}$ As a result, the board had to satisfy the "active supervision" prong of Midcal to be granted antitrust immunity under state action. ${ }^{111}$

Although the North Carolina State Board of Dental Examiners claimed their actions were in the interest of public health, those actions were not entitled to state-action antitrust immunity because there was no active supervision of the Board by the State even if the "clear articulation" standard was satisfied. ${ }^{112}$ Board interpretation of the Dental Practice Act was not supervised by the State. ${ }^{113}$ Therefore, the cease-and-desist letters that flowed

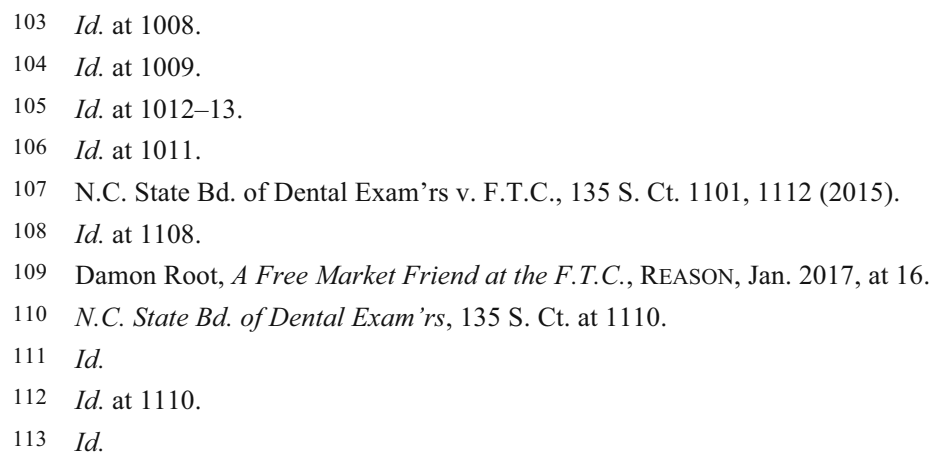


from the Board to would-be teeth-whitening competitors of the market participant Board members would not be entitled to immunity from the antitrust laws. ${ }^{114}$ In assuaging Justice Alito's federalism concerns over the Court's interpretation of "Parker Immunity" application, the Court stated:

The Sherman Act protects competition while also respecting federalism. It does not authorize the States to abandon markets to the unsupervised control of active market participants, whether trade associations or hybrid agencies. If a State wants to rely on active market participants as regulators, it must provide active supervision if state-action immunity under Parker is to be invoked. ${ }^{115}$

\section{E. Florida's CON Program}

The Florida CON program, which was established in 1973, has gone through changes since its adoption but still persists today. ${ }^{116}$ Florida adopted its CON program at a time when the state was experiencing a population boom, and regulators were concerned that unrestrained markets would lead to misallocation of health care markets and resources. ${ }^{117}$ The two overarching goals of the program that directed the attentions of regulators were access and quality. ${ }^{118}$ The factors that were to inform the decisions of CON program administrators were: the demographic characteristics of the population; the health status of the population; service use patterns, standards, and trends; geographic accessibility to needed services; and market economics. ${ }^{119}$

Florida's CON program administration is managed by the Agency for Health Care Administration (AHCA). ${ }^{120}$ This scheme's legal authority is derived from the Health Facility and Services Development Act, contained in sections 408.031 through 408.045 of the Florida Statutes, and Florida Administrative Code Chapter 59C-1. ${ }^{121}$ Under the framework, health care providers are required to obtain state approval before offering new or modified services. ${ }^{122}$ As defined by section 408.032, a "certificate of need" is a "a written statement issued by the agency evidencing community need

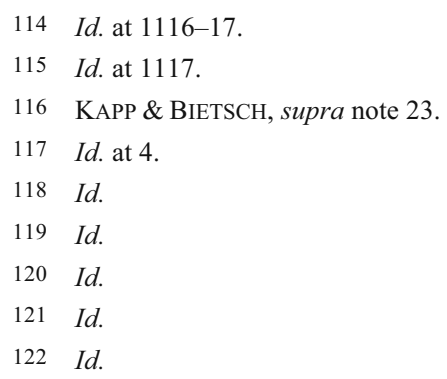


for a new, converted, expanded, or otherwise significantly modified health care facility, health service, or hospice." 123

The review criteria for $\mathrm{CON}$ applications are specified in section 408.035:

(1) The agency shall determine the reviewability of applications and shall review applications for certificate-ofneed determinations for health care facilities and health services in context with the following criteria, except for general hospitals as defined in s. 395.002:

(a) The need for the health care facilities and health services being proposed.

(b) The availability, quality of care, accessibility, and extent of utilization of existing health care facilities and health services in the service district of the applicant.

(c) The ability of the applicant to provide quality of care and the applicant's record of providing quality of care.

(d) The availability of resources, including health personnel, management personnel, and funds for capital and operating expenditures, for project accomplishment and operation.

(e) The extent to which the proposed services will enhance access to health care for residents of the service district.

(f) The immediate and long-term financial feasibility of the proposal.

(g) The extent to which the proposal will foster competition that promotes quality and cost-effectiveness.

(h) The costs and methods of the proposed construction, including the costs and methods of energy provision and the availability of alternative, less costly, or more effective methods of construction.

(i) The applicant's past and proposed provision of health care services to Medicaid patients and the medically indigent.

(j) The applicant's designation as a Gold Seal Program nursing facility pursuant to $\mathrm{s} .400 .235$, when the applicant is requesting additional nursing home beds at that facility. ${ }^{124}$

An application for a CON must contain: (1) a detailed description of the proposed project and statement of its purpose and need in relation to the district health plan; (2) a statement of the financial resources needed by and available to the applicant to accomplish the proposed project; and (3) an

\footnotetext{
123 FLA. STAT. § 408.032(3) (2017).

124 FLA. STAT. § 408.035(1)(a)-(j) (2017).
} 
audited financial statement of the applicant or the applicant's parent corporation if audited financial statements of the applicant do not exist. ${ }^{125}$ However, after jumping through all these hoops, applicants still are not guaranteed a fair shake at getting their CON granted. The agency has discretion to grant or deny the application. ${ }^{126}$ Additionally, section 408.039(5)(c) allows for competitors to have input in the decision making process ${ }^{127}$ Finally, competitors can even raise new challenges that were not raised before in a hearing if they think it will help them win a challenge against an applicant seeking to compete with them in their local market. ${ }^{128}$

Certain applicants even have "special requirements" which must show that the market they wish to enter into has a "need" for their services. ${ }^{129}$ Nursing home bed numbers are specifically limited. ${ }^{130}$

Today, Florida's CON program governs health care sectors such as new hospital facilities, replacement hospitals, Neonatal Intensive Care Unit (NICU) Level II and III and comprehensive medical rehabilitation beds, new long-term care hospitals, pediatric open heart surgery beds and cardiac catheterization services, organ transplantation services, new nursing home beds, replacement nursing homes, new hospice programs, new hospice inpatient facilities, and intermediate care facilities for the developmentally disabled. ${ }^{131}$ Although this represents a significant reduction in the size and scope of the original CON program, it is still a sufficiently large chunk of the health care market in Florida to have wide-ranging impacts and consequences on consumers, even in sectors untouched by the CON program. ${ }^{132}$

125 Fla. STAT. $\S 408.037(1)$ (a)-(c) (2017).

126 Id. at $\S 408.037(2)$ (stating that "[i]f, subsequent to issuance of a final order approving the certificate of need, the proposed location of the general hospital changes or the primary service area materially changes, the agency shall revoke the certificate of need. However, if the agency determines that such changes are deemed to enhance access to hospital services in the service district, the agency may permit such changes to occur. A party participating in the administrative hearing regarding the issuance of the certificate of need for a general hospital has standing to participate in any subsequent proceeding regarding the revocation of the certificate of need for a hospital for which the location has changed or for which the primary service area has materially changed").

127 FLA. STAT. $\$ 408.039$ (5)(c) (2017) (stating that "[e]xisting health care facilities may initiate or intervene in an administrative hearing upon a showing that an established program will be substantially affected by the issuance of any certificate of need, whether reviewed under s. 408.036(1) or (2), to a competing proposed facility or program within the same district”).

128 Id. (stating " $\mathrm{t}]$ he administrative law judge may, upon a motion showing good cause, expand the scope of the issues to be heard at the hearing. Such motion shall include substantial and detailed facts and reasons for failure to include such issues in the original written statement of opposition").

129 FLA. StAT. § 408.043(1)-(2) (2017). Osteopathic acute care hospitals and hospices respectively.

130 FLA. STAT. $\$ 408.0436$ (2017).

131 KAPP \& BIETSCH, supra note 23, at 3.

132 Id. 


\section{AnAlysis}

\section{A. CON Economic Impacts}

Recent studies on CON programs by the Mercatus Center at George Mason University have shown that many CON programs across the country have not only failed to achieve their intended goal, but in some cases have exacerbated the problem they were aimed at relieving. ${ }^{133}$ For example, researchers Thomas Stratmann and Jacob W. Russ have demonstrated that one of the primary aims of CON programs - to increase the supply of health care services (especially to the indigent) - has simply not materialized. ${ }^{134}$ CON programs seek to achieve increased access to health care by those who cannot afford it through a concept known as "cross-subsidization.","135

The aim of "cross-subsidization" is to limit competition to established health care providers by denying CONs to would-be competitors. ${ }^{136}$ By artificially depressing the supply of health care services, established providers are able to charge those who can afford the inflated health care costs that result from the artificial depression of supply more than they otherwise would be able to. ${ }^{137}$ In turn, this excess revenue that established providers receive as a result of the scheme is supposed to be used to provide free and below market cost health care services to the indigent. ${ }^{138}$ But, the bottom line of "cross-subsidization" is this: it is targeted directly at harming consumers who can pay for health care in order to benefit those who cannot. Rather than driving down prices so that all can afford quality health care, advocating for "cross-subsidization", in effect, is admitting defeat when it comes to health care costs.

However, the strategy of "cross-subsidization" to increase indigent care does not operate in a theoretical vacuum. The fanciful ideas of legislators and regulators do not operate apart from the market forces of the real world. Some providers may engage in "regulatory capture" and look at the increased profits accruing, as a result of regulation, as part of an overall strategy to maximize profits. ${ }^{139}$ Such providers retain the increased profits rather than put them to the intended goal of the regulation (i.e. providing below-market or free services to the indigent).

133 Mitchell \& Koopman, supra note 1.

134 ThOmas StRATMANN \& JACOB W. RuSS, Do CERTIFICATE-OF-NEED-LAWS INCREASE INDIGENT CARE? 18 (2014), https://www.mercatus.org/system/files/Stratmann-Certificate-of-Need.pdf.

135 Id. at 2.

136 Id.

137 Id.

138 Id.

139 Id. at 2 n.3. 
Although regulators may wish to prevent such activities, two reasons are identified by researchers Stratmann and Russ as to why providers behaving this way can fly under the radar of regulation. ${ }^{140}$ First, the numerous avenues by which health care providers can claim to be subsidizing indigent care makes it hard for regulators to determine if the providers are following the rules in one specific regulatory way. ${ }^{141}$ Second, the change in medical technology, increased prevalence of managed care organizations, decreased federal payments to Medicare, and deregulation has increased health care industry competitiveness since the 1980s, and medical providers have lower profits and less ability to provide cross-subsidies. ${ }^{142}$

As a result of their research, Stratmann and Russ found no evidence of effective "cross-subsidization" resulting either directly or indirectly from the operation of CON programs. ${ }^{143}$ They did find, however, that CON programs operate to restrict entry and limit the provision of regulated medical services. ${ }^{144}$ "For example, CON states have about 13 percent fewer hospital beds per 100,000 persons than non-CON states." ${ }^{145}$ Because various CON programs, among the several states that still have them, operate differently and regulate the twenty-eight areas of the health care market to varying degrees, Stratmann and Russ controlled for "stringency" to see how more or less CON regulation compares to each other from state to state. ${ }^{146}$ When controlling for "stringency", they found " 4.7 fewer hospital beds per 100,000 persons for each additional regulated service." 147 Additionally, they found reduced prevalence of hospitals with CT scanners, MRI machines, optical colonoscopy, and virtual colonoscopy in CON states. ${ }^{148}$ In real terms, the decrease in prevalence of these lifesaving machines may even cost lives.

CON programs have also been demonstrated to fail their intended objective in providing for more rural hospitals. ${ }^{149}$ To bring about increased access to hospital care in rural areas, CON programs limit "hospital substitutes"; chief among them are ambulatory surgical centers (ASCs). ${ }^{150}$ The rationale behind limiting such specialty health care providers was

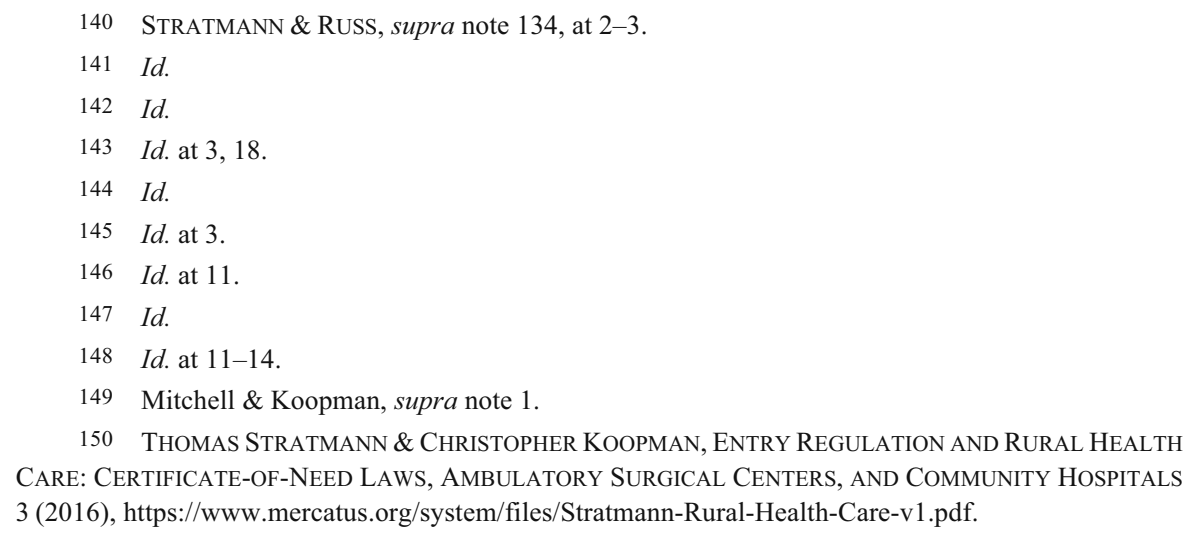

150 THOMAS STRATMANN \& CHRISTOPHER KOOPMAN, ENTRY REGULATION AND RURAL HEALTH

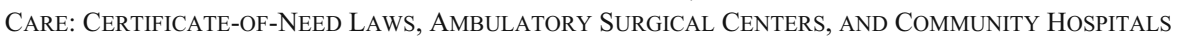
3 (2016), https://www.mercatus.org/system/files/Stratmann-Rural-Health-Care-v1.pdf. 
summed up in Colon Health Ctrs. of Am., LLC v. Hazel, 813 F.3d 145, 157 (4th Cir. 2016), which stated:

A related purpose of the CON program is geographical in nature. For reasons not difficult to discern, medical services tend to gravitate toward more affluent communities. The CON program aims to mitigate that trend by incentivizing healthcare providers willing to set up shop in underserved or disadvantaged areas such as Virginia's Eastern Shore and far Southwest. "In determining whether" to issue a certificate, for example, Virginia considers "the effects that the proposed service or facility will have on access to needed services in areas having distinct and unique geographic, socioeconomic, cultural, transportation, or other barriers to access to care." 151

According to supporters of CON programs, "hospital substitutes" like ASCs create a "cream skimming" effect on health care markets, which negatively impact traditional hospitals. ${ }^{152}$ By allowing free entry into health care markets to ASCs, rural areas suffer because traditional hospitals lose revenue, making it harder for them to stay in business, let alone provide free or reduced cost services to poorer rural areas. ${ }^{153}$ Allegedly, "ASCs will accept only the more profitable, less complicated, and well-insured patients while hospitals will be left to treat the less profitable, more complicated, and uninsured patients." 154

In particular, two claims in support of CON programs related to access to health care in rural areas were tested by researchers Stratmann and Christopher Koopman. ${ }^{155}$ First, whether "CON programs protect hospitals from competition by regulating the entry and expansion of nonhospital providers," resulting in more total community and rural hospitals. ${ }^{156}$ Second, whether "they protect access to rural care by regulating the entry and expansion of nonhospital providers," resulting in fewer total ASCs and rural ASCs in CON versus non-CON states. ${ }^{157}$

In regards to both claims, Stratmann and Koopman found the exact opposite to be achieved by CON programs aimed at increasing availability of

151 Colon Health Centers. of Am., LLC v. Hazel, 813 F.3d 145, 157 (4th Cir. 2016) (citing VA. CODE ANN. § 32.1-102.3(B)(1) (2017)).

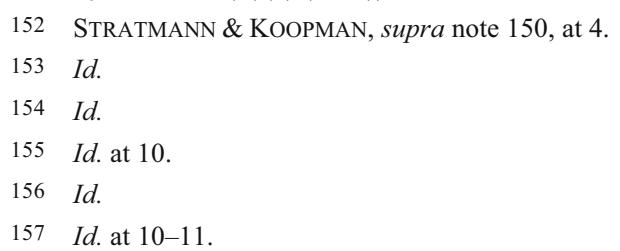


hospitals in rural areas. ${ }^{158}$ In fact, they found that states with CON programs which limit ASCs and other "hospital substitutes" thought to contribute to "cream skimming" have fewer rural hospitals per capita than states that do not have such CON programs. ${ }^{159}$ Specifically, they found:

[W] hen controlling for demographics and year-specific effects, the presence of a CON program is associated with 30 percent fewer total hospitals per 100,000 state population and 30 percent fewer rural hospitals per 100,000 rural population. Moreover, we find 14 percent fewer total ASCs per 100,000 state population and 13 percent fewer rural ASCs per 100,000 rural population. ${ }^{160}$

This is not surprising in light of the way these CON programs typically operate, namely to increase barriers to entry, especially in the areas targeted to access. ${ }^{161}$

The faulty conclusions of CON program proponents seems to be twofold. First, proponents assume that market effects such as "cream skimming" that would allegedly result in an unregulated entry to the market, are the primary, if not only, cause of hospitals closing up in rural and underserved communities. Second, proponents undervalue the negative effects of CON programs on service providers that may want to establish or reestablish in an area that is underserved. Obviously, if the intent of the program is to make it harder to establish a new service in a given area but not to prevent any number of reasons why the service may have left in the first place, the results found by Stratmann and Koopman are intuitive. Regardless of causes of decreased access to rural health care, CON programs not only have not achieved the intended goal of increased rural access to health care, but have actually created the opposite effect.

Another benefit, alleged by CON program proponents, is the effect on the quality of care at health care facilities. ${ }^{162}$ Proponents claim that CON programs "increase quality by channeling more procedures through fewer hospitals, allowing those hospitals to gain expertise." ${ }^{\prime 63}$ However, research conducted by Stratmann and David Wille found "no evidence that CON laws increase the quality of care." 164 They found "evidence consistent with the

158 Id. at 19

$159 I d$.

160 Id.

161 Id. at $17-18$.

162 Mitchell \& Koopman, supra note 1.

163 Id.

164 Thomas Stratmann \& DAVid Wille, Certificate-OF-NeED LAWs AND Hospital QUALITY 46 (2016), https://www.mercatus.org/system/files/mercatus-stratmann-wille-con-hospitalquality-v1.pdf. 
hypothesis that limiting entry results in lower hospital quality." rate differences between $\mathrm{CON}$ and non-CON states showed that:

$[\mathrm{M}]$ ortality rates are statistically significantly higher at hospitals in CON states than in non-CON states. Our findings show that the estimated average 30-day mortality rate for patients discharged with pneumonia, heart failure, or heart attack from hospitals in CON states is between 2.5 and 5 percent higher than the average mortality rate for all hospitals in our subsample of HRRs that contains providers in both CON and non-CON states, depending on the illness. These findings are largely robust to a variety of alternative samples and quality measures. ${ }^{166}$

Several different factors could explain these findings. However, one potential explanation stands out as the most obvious and logical: decreased competition leads to inferior service. ${ }^{167}$

Competition between firms in any market takes place at the margins. This is to say that the majority of costs to provide quality care will be essentially the same among providers; if providers are to compete, they must reduce costs on the marginal differences around the edges of the overall service they provide. In an industry that revolves around care quality, such as health care, it only makes sense that this is where providers will compete most vigorously in the absence of competition that forces them to keep quality up. In fact, other than technology, care quality is probably the most important margin on which hospitals compete. ${ }^{168}$ If established providers know that they do not have to compete in this area, or at least are forced to compete to a lesser extent, because other forces (CON programs) operate to exclude potential competition, then hospital administrators may make rational decisions about cutting corners in care quality to increase marginal revenue. ${ }^{169}$ "Decision makers in hospitals facing fewer competitive pressures may therefore set lower standards of quality or effort."170

One important factor that exacerbates the faulty incentive mechanism established by CON program operation is that another area of marginal competition, pricing, is fixed for health care providers. ${ }^{171}$ Since prices are generally determined administratively (think Medicare and Medicaid) rather

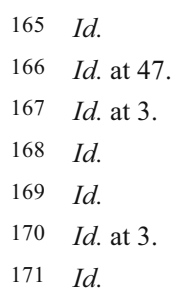


than by the market, providers are generally excluded from competing in that area. ${ }^{172}$ With price competition excluded, one of the biggest areas providers look to in order to compete is care quality. With varying degrees of intervention into the health care market by $\mathrm{CON}$ programs, unintended consequences become more pronounced. As opposed to a market system, where potential competitors would have free entry into the market and could compete in both pricing and quality, $\mathrm{CON}$ programs incentivize poor quality decisions to offset the ill effects of no price competition. ${ }^{173}$

Setting competition incentives aside, proponents argue that the expertise gained by providers, as a result of higher care volumes, is the reason for their claim of increased quality. ${ }^{174}$ The argument goes that because a higher volume of patients are funneled to established providers in a given area, those providers essentially get more practice and their care quality rises. ${ }^{175}$ Even taken at face value, this seems nonsensical because it ignores other operational realties of CON program operation. It assumes there is no limit to the amount of expertise a provider can gain from increasing the number of patients the provider sees. Conversely, it assumes that the provider and would-be competitors could not attain the same level of expertise with fewer patients. Finally, it completely ignores the effects on patient outcomes of delayed or denied care. If there are more potential patients that reside in a given area than the allotted for providers can handle, how many of those patients delay or forego needed medical care because the established providers simply cannot handle the volume? All of these factors could play a role in the findings of Stratmann's and Wille's research regarding diminished care quality in CON states versus non-CON states. ${ }^{176}$

The beneficial claims of CON programs on health care markets across the country are legion. But, although some studies conflict on CON program outcomes from state to state, the evidence in support of CON programs as beneficial to health care consumers is tenuous at best. Several studies targeting several claims about the benefits of CON programs and their corollary factors on health care consumers have shown the alleged benefits of CON programs to be unpersuasive or non-existent.

$\begin{array}{ll}172 & I d . \text { at } 3-4 . \\ 173 & I d . \text { at } 4 . \\ 174 & I d . \\ 175 & I d . \\ 176 & I d . \text { at } 7 .\end{array}$




\section{B. Perverse Incentives Create Perverse Results}

CON programs across the country are built on outdated and faulty logic. The outdated arguments for CON program necessity centers around health care reimbursement incentives. ${ }^{177}$ Although legislators were chiefly concerned with reimbursement incentives for capital expenditures in health care when CON programs were first adopted, health care is largely no longer reimbursed in the same way. ${ }^{178}$ "Instead, the federal government establishes universal reimbursement rates for Medicare and Medicaid, and private insurers negotiate payments procedure by procedure rather than by provider cost." ${ }^{\prime 179}$ This reimbursement structure almost completely vitiates incentives to unnecessarily improve one's health care service through capital improvements. ${ }^{180}$ Accordingly, arguments in defense of CON programs, predicated on alleged "market failures" of perverse reimbursement incentives, are based on factors that no longer exist. ${ }^{181}$

The faulty logic, in support of CON programs, is premised on a simplistic view of how market participants are incentivized and a naïve view of how central planners are incentivized. ${ }^{182} \mathrm{CON}$ program proponents seem to have a "fixed pie" view of the market, in which actions taken by market participants have zero-sum outcomes. However, this simplistic view of the market does not account for the complex and dynamic forces of supply and demand.

In addition to the complex network of business decisions and outcomes that stem from each action decided on by participants, the overlooked aspect of decision-making by market participants is that they are directly interested in the outcomes of their decisions. ${ }^{183}$ Because market participants are directly interested in the viability of their firms relative to their competitors, they must account for the full range of complexity in market competition with those competitors. They cannot simply ignore the detriment to their consumer base from inflating the cost of their service (or forego the goodwill of serving the underserved at reduced prices) in the pursuit of unnecessary capital improvements. Market participants must consider all possible benefits and burdens placed on their bottom lines as a result of the decisions they make. If they ignore, overlook, or underestimate one factor in shortsighted pursuit

$\begin{array}{ll}177 & \text { Ohlhausen, supra note 3, at } 51 . \\ 178 & \text { Id. } \\ 179 & \text { Id. } \\ 180 & \text { Id. } \\ 181 & \text { Id. } \\ 182 & \text { Id. } \\ 183 & \text { Id. }\end{array}$


of an overestimated alternative factor, they run the risk of becoming less competitive overall and possibly going out of business.

Central planners, on the other hand, do not face these same pressures. "Government actors respond to political pressure, often exerted by special interests that seek to place their own, narrow interests ahead of the general public welfare." ${ }^{\prime 84}$ In effect, CON programs create a scheme of consolidated benefits and dispersed costs. Established health care providers are presented with a new incentive (one which would not exist in a free market) to curry favor with CON regulators to limit competition rather than compete openly with competitors. These established providers are the small group who benefit from CON programs to the detriment of consumers and would-be competitors, who bare the dispersed costs. However, "[h]istory amply demonstrates that central economic planning is inefficient and deeply harmful to the societies that practice it." 185 "In short, there are some very good reasons why the government typically stays out of this kind of private economic activity in other parts of the economy. None of those general concerns disappears simply because we are talking about health care." 186

In light of the practical realities of CON program operation, the problem of the "consumer benefit" rationalization begins to come into focus. Economic research has substantially disproven the alleged benefits to consumers that proponents have put forward, in defense of CON programs, over the years. By applying that research to the objective of antitrust law, CON programs are operating on legal thin ice.

\section{Florida's CON Program Violates the Rule of Reason and Antitrust Law}

Antitrust law and, in particular, the "rule of reason" are specifically targeted at protecting consumers. ${ }^{187}$ The rationale and principles which undergird antitrust law to effectuate that goal are sound and should guide analysis of public policies as vigorously as private actions. As the "comprehensive charter of economic liberty," the Sherman Antitrust Act is proffered against private action to prevent "unreasonable" restraints of trade. ${ }^{188}$ The Clayton Act targets mergers and acquisitions that substantially lessens competition or tends to create monopolies. ${ }^{189}$ Finally, the Federal

$\begin{array}{ll}184 & I d . \\ 185 & I d . \\ 186 & I d . \\ 187 & \text { The Antitrust Laws, supra note } 13 . \\ 188 & I d . \\ 189 & I d .\end{array}$


Trade Commission Act forbids unfair methods of competition and deceptive acts or practices. ${ }^{190}$

Florida's CON program unreasonably restrains trade in the health care market to the same, or worse, extent as any private action in any other market segment that is subjected to the Sherman Antitrust Act. Despite the general welfare claims that allegedly supports Florida's CON program, the empirical evidence demonstrates that it violates the "rule of reason" because it operates for the sole benefit of established health care providers, to the detriment of competitors, trade, and consumers. ${ }^{191}$ Considering the factors articulated by Justice Brandeis in Chicago Board of Trade v. United States, 246 U.S. 231 (1918), Florida's CON program falls squarely within "rule of reason" violation. ${ }^{192}$ When the history of CON program adoption and operation is viewed through the lens of its practical effects rather than its theoretical defenses, it becomes clear that the restraint on health care that CON programs create do anything but assure economic liberty and fair competition. ${ }^{193}$

The three prong test of the "rule of reason" analysis, as related to Florida's CON program, can be answered as follows. ${ }^{194}$ First, health care market competitors are prevented from competing with established industry providers because established providers are protected by indefinite requirements that competitors simply cannot meet. ${ }^{195}$ Second, although the objectives of Florida's CON program operation are legitimate ones, there are little or no "redeeming virtues" in the effects of the CON program operation, as bared out in the research. ${ }^{196}$ Finally, there are other ways for Florida to achieve its legitimate health care objectives with fewer harms to competition. ${ }^{197}$ In short, Florida's CON program operates purely to the benefit of established industry providers, and to the detriment of competitors, trade, and consumers. ${ }^{198}$

Florida's CON program fails the first prong of the "rule of reason" test because it limits competition in two symbiotic and pernicious ways. First, Florida's CON program sets indefinite criteria that would-be competitors must meet before being granted their permission to compete. ${ }^{199}$ Second, established providers can object to the granting of a CON with the age-old,

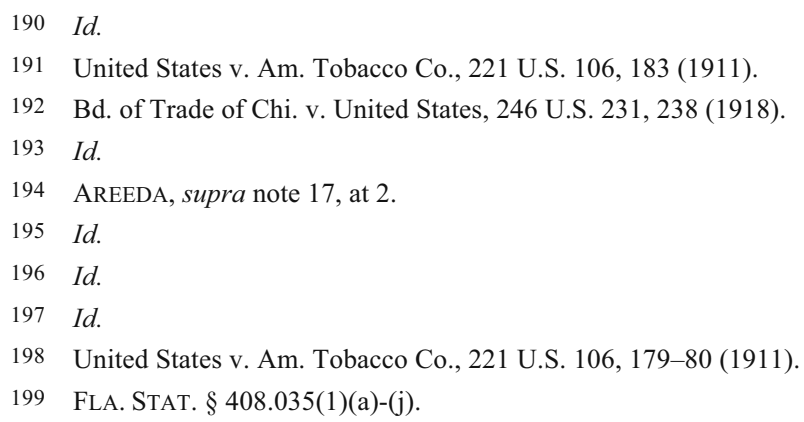


non-descript, platitude of "public interest." ${ }^{200}$ Florida's CON program, in particular, is a perfect example of this interplay between indefinite terms and generic appeals to "public interest."

Section 408.035(1)(a)-(j), Florida Statutes, sets out a laundry list of criteria that helps $\mathrm{CON}$ regulators determine if $\mathrm{CON}$ applications are reviewable. ${ }^{201}$ Factors include: (1) the "need" for the new facility or service; ${ }^{202}(2)$ the "availability" of the service already provided in a given area $^{203}$ (3) the "ability of the applicant to provide quality care;",204 (4) the "extent to which the proposed service will enhance access;" 205 (5) the "immediate and long-term financial feasibility;" ${ }^{206}$ (6) the "extent" to which competition will be fostered, ${ }^{207}$ and (7) the applicant's past and future provision of health care to Medicaid and medically indigent. ${ }^{208}$ Taken as a whole, the list seems comprehensive.

However, considering that granting or denying of the application is in the discretion of the agency, each criteria acts more like a mine in a battlefield than a detailed, required course of action. ${ }^{209}$ What is a "need" for a new service or facility? How is this nebulous concept to be satisfied? What is an applicant to say about their "ability to provide quality care," other than "we can?" And what if CON regulators simply disagree? How can anyone predict the "extent" to which a proposed service or facility will "enhance access," other than it obviously would?

New providers may know their immediate financial feasibility, as identified by their market research and initial capital investment. But, can not knowing or not anticipating every potential impact on their continued success that arises from a dynamic market be held against them? Even with this in mind, new providers cannot possibly predict new costs that have an impact on their financial feasibility from future government interventions and regulations, which is an ever-present threat. Would not knowing this, or failing to accurately predict it for inclusion into a long-term financial feasibility analysis, be held against them?

What "extent" of competition fostering must the proposed service or facility reach to be acceptable to regulators? What established provider would

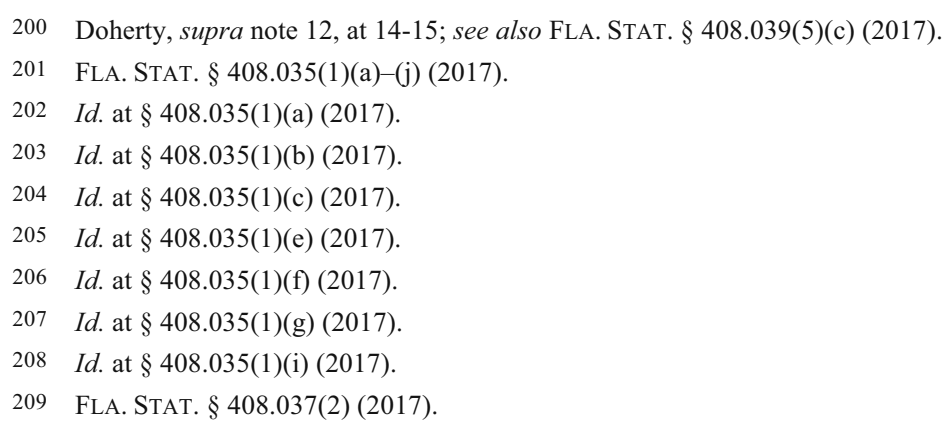


not object to any "extent" of increased competition? ${ }^{210}$ How is a new applicant supposed to answer past service to Medicaid or the medically indigent if this is their first attempt? How can they answer to future service for the same groups without having operated before? Is "we promise to serve Medicaid patients and the medically indigent" enough? "We promise $20 \%$ of our services to them?" " $40 \%$ ?" " $75 \%$ ?" " $99 \%$ ?" These indefinite criteria make it all too easy for established providers to object and regulators to deny proposed CON programs.

Section 408.039(5)(c), Florida Statutes, allows "existing health care facilities" to intervene at any time and object to the issuance of a CON. ${ }^{211} \mathrm{In}$ fact, they continue to do so. ${ }^{212}$ Other than objecting to lack of need for a new service or facility in a given area, Florida providers can object on "public interest" grounds as other providers have done again and again in other states that still have their own CON programs. ${ }^{213}$ Despite the litany of evidence that refutes any idea that limiting competition in health care is in the "public interest" of Florida residents, this blind appeal to theoretical ideals often trumps empirical findings. ${ }^{214}$ Perhaps the most troublesome aspect of section

210 Matthew Glans, Research \& Commentary: Certificate of Need Reform in Florida, HEARTLAND INST., https://www.heartland.org/publications-resources/publications/research—commentary-certificateof-need-reform-in-florida (last visited Jan. 2, 2017) ("This scenario is now happening in Florida. Five hospitals, including Coral Gables Hospital, Hialeah Hospital, Palmetto General, Kendall Regional Medical Center, and Nicklaus Children's Hospital, are challenging a ruling made by the Florida Agency for Health Care Administration (AHCA). The ruling approved plans for a new Jackson Health System (JHS) hospital in Doral, Florida. The five hospitals appealing the decision are attempting to use the CON process to block a competitor from entering their market, claiming there is not a need for a new facility in the proposed area. JHS plans on continuing with its construction plans, which include a standalone emergency room, a pediatric center, physician offices, and facilities for performing outpatient surgeries, according to the Miami Herald.”).

211 FLA. STAT. § 408.039(5)(c) (2017).

212 Glans, supra note 210.

213 Doherty, supra note 12; see also FLA. STAT. § 408.039(5)(c) (2017).

214 Christopher Koopman \& Thomas Stratmann, Mercatus on POL'y, Certificate-OFNEED LAwS: IMPLICATIONS FOR FLORIDA (2015), https://www.mercatus.org/system/files/KoopmanCertificate-of-NeedFL-MOP.pdf ("In particular, Stratmann and Russ present several striking findings regarding the provision of health care in states implementing CON programs. First, CON programs are correlated with fewer hospital beds. Throughout the United States there are approximately 362 beds per 100,000 persons. However, in states such as Florida that regulate acute hospital beds through their CON programs, Stratmann and Russ find 131 fewer beds per 100,000 persons. For a county like Miami-Dade, with its population of approximately 2.62 million, this means that there are about 3,428 fewer hospital beds as a result of the state's CON program. Moreover, several basic health care services that are used for a variety of purposes are limited because of Florida's CON program. Across the United States, an average of six hospitals per 500,000 persons offer MRI services. In states such as Florida that regulate the number of hospitals with MRI machines, the number of hospitals that offer MRIs is reduced by between one and two per 500,000 persons. As a result, in an area like Miami-Dade County there are approximately five to ten fewer hospitals offering MRI services. Florida's CON program also affects the availability of CT services. While an average of nine hospitals per 500,000 persons offer CT scans, CON regulations are associated with a 37 percent decrease in these services. For the 2.62 million people living in Miami-Dade, this could mean about 18 fewer hospitals offering CT scans"). 
408.039(5)(c) is the ability of established providers to raise any of these issues even if not originally included in the first proceeding. ${ }^{215}$ Sure, providers must back up these late requests with "substantial and detailed facts" as to why a new issue was not raised initially, but considering the success that Florida's CON program has apparently provided to established providers, this does not seem to be much of a procedural constraint on challenges to new CON issuance. ${ }^{216}$

CON programs fail the second prong of the "rule of reason" test because the nature and magnitude of alleged "redeeming virtues" of the restraint the programs put on competition do not outweigh the restraints themselves. ${ }^{217}$ CON program proponents have never been bashful about how the programs are to operate. CON programs have long been intended to limit the supply of health care services in states that have them. ${ }^{218}$ These same proponents assert that the limits were necessary to control costs or increase charity care. ${ }^{219}$ "However, forty years of evidence demonstrate that these programs do not achieve their intended outcomes but rather decrease the supply and availability of health care services by limiting entry and competition.",220

Not only do CON programs not achieve their goals (and in some cases, achieve the opposite), the minimal benefits to consumers are negligible and unpersuasive when comparing "redeeming virtues" to competition restraint. ${ }^{221}$

When deregulation went into effect, per capita health care spending dropped and the quality and availability of service rose, thus providing a benefit to consumers. By contrast, they found that in those states that continued to require CONS, the effect of the regulations on per capita spending was not significant, nor did it work to increase availability or quality. Hence, there was little or no benefit to consumers. What was significant in those states retaining CONS, though, was the effective stifling of competition and the raising of existing providers' profits. ${ }^{222}$

In other words, the theoretical justifications of CON programs have not materialized into tangible "redeeming virtues" sufficient to outweigh the

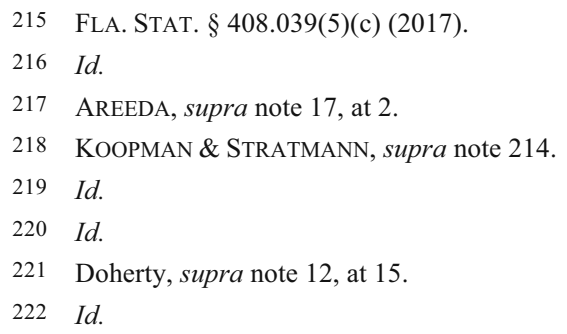


restraints CON programs place on competition or sufficient to pass the second part of the "rule of reason" test.

CON programs fail the third prong of the "rule of reason" test because there are less restrictive (and more transparent) alternatives to achieve the objective. ${ }^{223} \mathrm{CON}$ programs often fail their objectives because no one, including the regulators, know where or how the increased profits that result from CON programs are distributed. ${ }^{224}$ Established health care providers that do a poor job of servicing indigent care are rewarded by CON programs as much or more than those that do a much better job. ${ }^{225}$ "A poorly performing provider in an area where $\mathrm{CON}$ laws exclude entrants and drive up prices will benefit much more than a top-tier provider in an area with flat demand and plenty of existing competition." 226 Even where CON programs expressly require that beneficiaries provide care for the medically indigent, no one knows which providers are benefitting from CON programs without holding up their end of the deal. ${ }^{227}$ Accordingly, there is no way to assure how much, if any, of the increased profits, realized by established providers, is going to care for the indigent. ${ }^{228}$

Maureen K. Ohlhausen, the current Commissioner of the Federal Trade Commission, has argued that $\mathrm{CON}$ programs violate "fundamental norms of good government."229 For commissioner Ohlhausen, the change in health care payment structures since the 1970s, as well as the empirical evidence that demonstrates that CON programs cannot and do not achieve their intended goals of caring for the medically indigent, provide ample reason why CON programs should be abandoned. ${ }^{230}$ She argues that:

[U]sing laws passed over 40 years ago and designed to achieve something completely different is not the most direct or efficient way to achieve that end. Granting providers even a limited exemption from the competitive process is an exceptionally poor and nontransparent way to achieve any public policy goal, much less one as important as indigent care. In a democracy, when the government takes money from the people to fund public works, those actions should be transparent so that the government is ultimately politically accountable for its actions. CON laws use the

$\begin{array}{ll}223 & \text { AREEDA, supra } \text { note } 17 . \\ 224 & \text { Ohlhausen, supra } \text { note } 3 \text {, at } 53 . \\ 225 & \text { Id. } \\ 226 & \text { Id. } \\ 227 & \text { Id. } \\ 228 & \text { Id. } \\ 229 & \text { Id. } \\ 230 & \text { Id. at } 53 .\end{array}$


power of government to shift funds from private payers to providers, but where and how much money is transferred remains opaque. ${ }^{231}$

Simply put, CON programs do not provide sufficient oversight of health care industry providers to assure that the alleged social benefits of CON programs are truly effectuated. ${ }^{232}$ "States that deem indigent care mandates necessary should fund them directly and publicly, rather than through an opaque transfer of those costs onto the insured public. Good government demands both transparency and political accountability."233

\section{Parker Immunity Should Not Be Applied to Florida's CON Program}

In light of the Supreme Court's recent opinions clarifying the Midcal two-part test for Parker immunity application to private action, Florida's CON program should not receive state-action immunity. ${ }^{234} \mathrm{CON}$ program proponents disagree that $\mathrm{CON}$ programs obviously operate to unnecessarily impede market competition. ${ }^{235}$ If they are correct, then CON programs fail the first prong of the Midcal analysis to apply Parker immunity to private action. ${ }^{236}$ However, even if CON proponents decide to take economics 101 and come around to the idea that CON programs clearly burden market competition, CON programs would still fail prong two of the Midcal analysis. ${ }^{237}$ In either case, CON programs do not deserve state-action immunity for the regulation of a market by private actors.

The first prong of the Midcal analysis is the "clearly articulated" prong. ${ }^{238}$ In a recent case, F.T.C. v. Phoebe Putney Health Sys., 133 S. Ct. 1003 (2013), the Court clarified that a state policy is "clearly articulated" when legislative action creates an anticompetitive effect that was a "foreseeable result" of that action. ${ }^{239}$ Such anticompetitive effects are "foreseeable" when they are the "inherent, logical, or ordinary result of the authority delegated to the state legislature." ${ }^{40}$ In other words, when

231 Id.

232 Id.

233 Id.

234 F.T.C. v. Phoebe Putney Health Sys., 568 U.S. 216 (2013); N.C. State Bd. of Dental Exam'rs v. F.T.C., 135 S. Ct. 1101 (2015).

235 Ohlhausen, supra note 3, at 51.

236 Cal. Retail Liquor Dealers Ass'n v. Midcal Aluminum, 445 U.S. 97, 105 (1980).

237 Id.

238 Id.

239 Phoebe Putney Health Sys., 568 U.S. at 228-29.

240 Id. 
legislation could, would, or does obviously impede competition. Proponents could easily satisfy this prong if they simply accept the surfeit of economic facts. $^{241}$ However, as stated previously, CON program proponents are reluctant to concede that $\mathrm{CON}$ programs operate to impede market competition. ${ }^{242}$ Whatever their tactic, the law does not allow them to have their cake and eat it too. If proponents continue to deny the wealth of research that refutes their claims that CON programs do not unnecessarily create anticompetitive effects, then the anticompetitive effects that are identified are not the "inherent, logical, or ordinary result of the authority delegated by the state legislature." ${ }^{243}$ If their argument is taken at face value, it fails prong one of Midcal. ${ }^{244}$ On the other hand, if CON proponents accept the economic data, and admit that CON programs operate to create anticompetitive effects, they survive prong one of Midcal but now have to deal with prong two. ${ }^{245}$

The second prong of the Midcal analysis is the "active supervision" prong. ${ }^{246}$ N.C. State Bd. of Dental Exam'rs v. F.T.C., 135 S. Ct. 1101 (2015), recently provided vital insight to the application of Parker immunity concerning this "active supervision" prong. ${ }^{247}$ Although the AHCA is not a "market participant" in the way that the state dental board was in N.C. State $B d$. of Dental Exam'rs, the Florida CON program regime operates on significant input and control from market participants. ${ }^{248}$ Throughout the CON review process, market participants can interject themselves into the decision making of the AHCA, or place barriers in front of would-be competitors. ${ }^{249}$ By the time the AHCA gets around to making its final determination, the damage could already have been done. In such a highly regulated industry like health care, where profit margins are already vanishingly slim, each of the interjections in the CON decision-making process operates as a market participant constructed barrier. ${ }^{250}$ Even in a situation where a $\mathrm{CON}$ is granted, the delay to startup, and thereby revenue production, caused by established provider interventions into the AHCA's decision-making process could be a death knell to a new provider's long-term viability. How long would potential investors be willing to wait to begin seeing a return before they realize the investment juice simply is not worth

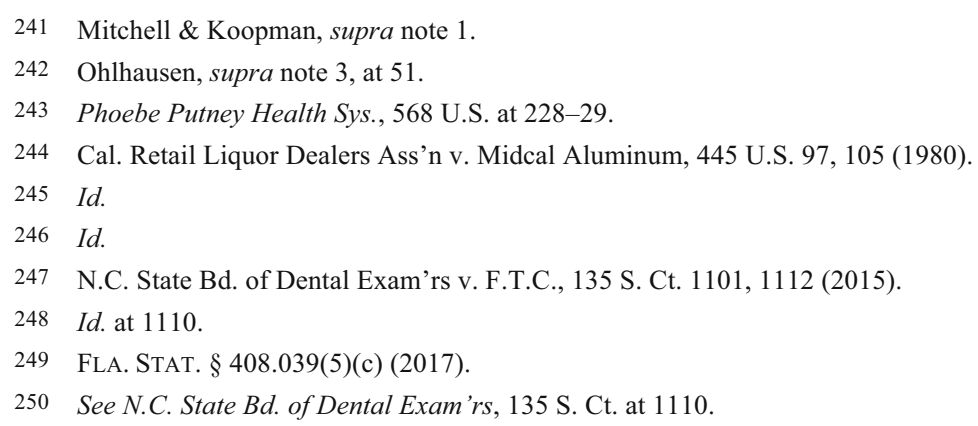


the squeeze? These delays by market participants could operate as a prophylactic barrier to competition. In this environment, the final decisionmaking process of the AHCA means very little when we consider the practical barriers to competition from such a regime.

This is simply too much private action into the regulatory process to warrant immunity under state-action. This collusion between the AHCA and market participants to bar entry into the Florida health care market is the type of "hybrid agency" identified by the Supreme Court in N.C. State Bd. of Dental Exam'rs. ${ }^{251}$ A relationship this close between the AHCA and market participants cannot satisfy the "active supervision" prong of Midcal. ${ }^{252}$ The pervasive nature of market participant involvement in the Florida CON program operation does not entitle the program to state-action immunity under Parker. ${ }^{253}$

\section{CONCLUSION}

Although, it is true that governments may exempt themselves from the laws they create, it is not true or right that they should. Where CON programs, such as Florida's, violate the "rule of reason" and the principles of consumer protection that underlie antitrust law, they should be eliminated.

Florida's CON program violates the Sherman Antitrust Act, the Federal Trade Commission Act, and the Clayton Act. ${ }^{254}$ Florida's CON program unreasonably restrains the ability of new potential competitors in the health care market from entering the market to compete with established providers. ${ }^{255}$ It facilitates "unfair methods of competition," which tends to "substantially [ . . ] ]lessen competition, or [ . . ] ]create a monopoly." 256

Applying the "rule of reason" to Florida's CON program, it has not been shown to create for consumers, the positive benefits alleged by its proponents. ${ }^{257}$ In fact, it has either created no beneficial effect at all or done the exact opposite of its stated goal. Creating more benefit than burden to Florida's health care consumers, Florida's CON program should be viewed with the same disdain by policy makers and courts as any private sector collusive activity.

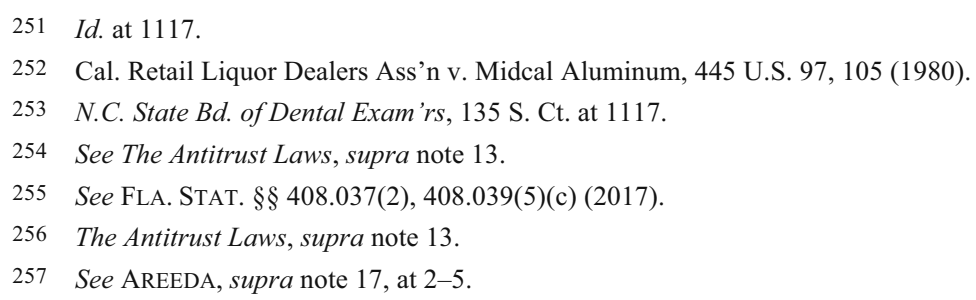


Instead of helping consumers by keeping prices down and access high, CON programs can be "distorted into a tool for the protection of established provider interests." ${ }^{258}$ This is especially true because the Agency for Health Care Administration (AHCA), which administers the program, is not subject to the same legal restraints on collusive activities as are private actors. ${ }^{259}$ Established industry providers know that if they appeal to regulators to deny CONs to would-be competitors by intervening in the approval process, they are likely to halt or at least substantially slow down the process. ${ }^{260}$ In fact, "[t] he current program proponents are comprised primarily of representatives of the still-regulated industries - hospices, hospitals, and nursing homes."261 In short, Florida's CON program places potential competitors behind the regulatory eight ball by stacking the deck in favor of their established competitors.

Especially problematic is the interplay between sections 408.037(2) and 408.039(5)(c) of the Florida Statutes. Because section 408.037(2) allows for a party participating in the administrative hearing to have standing to remain in subsequent hearings and section 408.039(5)(c) allows competitors to initiate or intervene in an administrative hearing, private competitive forces can harness the power of Florida's CON program for anticompetitive purposes. ${ }^{262}$ Even if established providers do not convince the AHCA to outright deny a CON, the delay they can place on a new potential competitor operates as an impermissible private action under the guise of government authority. This type of activity should not be entitled to Parker immunity.

On some level it appears that Florida legislators and regulators have already begun to understand some of these problems. ${ }^{263}$ This is demonstrated by the significant reduction in CON program reach into health care sectors since 1973. ${ }^{264}$ The Florida CON program, at one time "employed more than 40 full-time staff dedicated to CON review; today, four fulltime staff is adequate for that role." ${ }^{265}$ In 1985, 542 CON applications were reviewed; in 2010, only 39 CON applications were reviewed. ${ }^{266}$ This trend should continue all the way down to zero staff, reviewing zero applications, in 2017 and beyond.

258 Ken Wing \& A. G. Schneider, National Health Planning and Resources Development Act of 1974: Implications for the Poor, 9 CLEARINGHOUSE REV. 683, 691 (1976).

259 See Parker v. Brown, 317 U.S. 341, 351-52 (1943).

260 See FlA. STAT. § 408.039(5)(c) (2017).

261 See KAPP \& BIETSCH, supra note 23.

262 FLA. STAT. $\S \S 408.037(2), 408.039(5)$ (c) (2017).

263 See KAPP \& BIETSCH, supra note 23, at 3.

264 Id.

265 Id.

266 Id. 
Florida's CON program is violative of the Sherman Antitrust Act; therefore, it should be struck down. Florida's CON program impermissibly creates and protects monopolies in the health care industry, which violates the "rule of reason." Analyzed under the "rule of reason," Florida's CON program should be considered illegal because its effects unreasonably restrains trade and produces numerous ill effects to markets and consumers. Further, Florida's CON program does not generate sufficient "redeeming virtues" to save it from its harmful effects on competition. ${ }^{267}$ Finally, there are less burdensome options available for Florida to achieve its health care objectives.

In particular, studies have shown that Florida's CON program creates fewer hospital beds, MRI machines, and CT scan machines. ${ }^{268}$ The alleged benefits of "cross-subsidization" to achieve better access to unpaid services for the poor with paid services of the wealthier has not materialized. ${ }^{269}$ Additionally, the contentions that an unregulated health care market would lead to decreased health care access in rural and poor communities while simultaneously decreasing quality of care overall have been proven unpersuasive by the research. ${ }^{270}$ Florida's CON program has achieved its goal of limiting supply of health care but has not produced any material benefit of cheaper health care costs, increased care for the poor, or increased quality of care. ${ }^{271}$ In short, forty years of Florida's CON program has been all buck and no bang for Florida's health care consumers.

What is good for the goose is good for the gander. If antitrust law is aimed at protecting consumers from collusive practices in markets by private actors, then governments should be barred from the same types of activities when their actions are shown to violate the "rule of reason." Governments should not be able to collude with politically connected industry leaders to stifle competition under false premises of beneficial market regulations when those regulations have proven to cause more harm than good for forty years. Good intent does not forgive bad outcomes. Florida's CON program should be relegated to the dustbin of history once and for all, because lawmakers themselves should not be exempt from the laws they create.

\footnotetext{
267 AREEDA, supra note 17, at 5.

268 KOOPMAN \& STRATMANN, supra note 214, at 2.

269 STRATMANN \& RUSS, supra note 134 , at 18.

270 Mitchell \& Koopman, supra note 1.

271 KOOPMAN \& STRATMANN, supra note 214.
} 